\title{
Legal AIDS: Implications of AIDS and HIV for British and American law
}

\author{
Alistair Orr Balliol College, Oxford
}

\section{Author's abstract}

In its approach to AIDS and HIV the law has to protect two conflicting interests; it must recognise the right of the public to be protected against the disease and it must recognise the right of the individual not to be unfairly restricted by having or being at risk of the disease.

Consequently the law must make some compromise which while protecting public health also protects the individual so that the individual will feel free to come forward for available treatment. In this way prevention of spread of the disease is encouraged.

How this compromise is or might be affected by British and American law is examined in several areas, including medico-legal matters, criminal and tort law, employment, insurance and education.

\section{Introduction}

Acquired Immune Deficiency Syndrome (AIDS) and the virus which may progress to AIDS, Human Immunodeficiency Virus (HIV) present a paradox for their human hosts. For most people, although not all, the risk of contracting AIDS and of death from AIDS comes from the very act which creates life, that of sexual union. In a somewhat similar fashion the law, in reacting to AIDS and HIV, is forced to act in ways which can appear, at first sight, to be contradictory. Essentially the law must reconcile the dilemma created by the individual asserting a right to control over his or her life against the public right to be protected from this terrible affliction.

If AIDS is to be tackled then those who have the virus and those most at risk must be able to seek what treatment is available and, simultaneously, provide the health services with information not only about the spread of the disease but also about its very nature. Against this there is the public need to restrict conduct which is likely to spread the disease. Often this is conduct which many find morally offensive and yet which many others would argue was their right to enjoy. Those who have found themselves to have the virus or even to have been at risk of the virus have been

\section{Key words}

AIDS/HIV and the law; confidentiality and AIDS/HIV; medico-legal aspects of AIDS/HIV. subjected to all kinds of discrimination on both sides of the Atlantic in such fields as education, employment, housing and insurance. One particular issue is where a health care professional refuses to treat a patient because of the condition. Whilst much of the information here is only anecdotal, there are strong arguments for discouraging this attitude amongst medical professionals. The United States private health-care system is open to different pressures from the British public health-care system but a nursing home in New York was prevented from accepting AIDS patients by a group of neighbouring residents (1) and, in Los Angeles, two paramedics who allegedly did not provide prompt medical assistance to the victims of heart attacks were sued (2). Fear of AIDS motivated the action of the neighbours of the nursing home and the hesitancy of the two paramedics. In the United Kingdom, on the other hand, the Royal College of Nursing has warned that those nurses who refuse to care for AIDS victims face disciplinary action for unprofessional conduct (3). Although there have been calls for doctors to follow suit (4), nothing has as yet been done. It has been pointed out that there is a very strong ethical obligation on the doctor to treat the AIDS patient and if the doctor's refusal to treat such a patient is based on the notion that the illness resulted from voluntary conduct of which the doctor disapproves, then he leaves himself open to a charge of serious professional misconduct before the General Medical Council (5). While doctors do, reasonably, have fears about contracting the disease, basic precautions should guarantee their safety (6) and, given the feelings of hysteria which the AIDS virus can all too readily summon, there should be a special onus on the medical profession to be properly informed about the disease and to act in a manner which allays public fears and misapprehensions. The issue of a right to treatment again comes back to the fundamental difficulty that must be resolved by the law concerning this disease. Firstly, recognition must be given to the fact that the public are apprehensive of this mysterious and potentially lethal disease and that they wish to be given some sort of legal protection against it. Secondly and against this, those who have the disease and - of equal importance - those who are seen as being at risk of contracting the disease, must not be unduly ? 
restricted or imposed upon by society as a whole, and any restrictions which are placed upon them must be equitable. Essentially, what is at issue here is a matter of constitutional law. Because of the way in which the American and British legal systems have developed they have different approaches to tackle this.

\section{Constitutional law: a) the American position}

In the United States, it is possible, under the Constitution and Bill of Rights, for the Supreme Court to challenge any laws as violating the rights of individuals to, for example, liberty, privacy or property (7). What the courts are increasingly forced to do is to balance rights issues.

Different individual rights have independent positive weights and weights of different value (8) and assessing what these are has become firmly entrenched in constitutional decision-making. The case of New York State Association for Retarded Children $v$ Carey (9) held that the health risk posed by pupils with Hepatitis B was not sufficient to outweigh the burden on individual rights necessary for these children to be taught in segregated classes. Civil liberties then need not always yield to health risks, but it is too early to say how the courts will react to AIDS. What can be said is that some states have introduced laws demanding the reporting of all AIDS cases, establishing the mandatory reporting of HIV test results, and closing down places that permitted high-risk activity. Some states have also modified their laws to allow measures to be taken against those persons who expose others to a risk of infection.

Are the current protections sufficient? In particular, male homosexuals (the group most seriously affected by the disease at present) feel that an epidemic of discrimination is accompanying the epidemic of the disease and lawyers have noted that this discrimination is driving AIDS victims underground (10).

Some jurisdictions, notably the city of Los Angeles, have passed legislation to prohibit discrimination. The Los Angeles Ordinance provides the aggrieved person with a means for raising a civil action for damages, costs and punitive damages, and can be used by way of injunction (ie a court order prohibiting a particular act either before it occurs or while it is taking place). This is especially useful to someone with AIDS or HIV as the prospect of monetary relief after a prolonged court battle could prove pointless for such a person and because it greatly increases his power over the person exercising discrimination. While this local statute does provide a protection against discrimination it is also to be applauded for the role that it takes in trying to educate the public about the AIDS virus (11). It is, however, a unique phenomenon and the protection which it offers is not available in most parts of the United States.

\section{Constitutional law: b) the British position}

The British constitutional position is significantly different; there is no written constitution and no bill of rights. Discrimination has been addressed at a legislative level with regard to both sex and race, but little has been done outside that. In Britain, then, it would be very difficult to prove that one had been subjected to unfair treatment through being seen as at risk of contracting AIDS or HIV (although it may be possible to rely on other legislation, for example, prohibiting unfair dismissal from employment).

Certain laws have been passed in the United Kingdom which do have reference to the AIDS virus. The Public Health (Infectious Diseases) Regulations 1985 (12) did not make AIDS a notifiable disease, largely because the disease is not particularly infectious and to do so would have put unacceptable restrictions on sufferers. On the other hand, the Public Health (Control of Diseases) Act 1984 allows, in 'exceptional circumstances', for patients believed to have AIDS to be compulsorily examined and those with AIDS to be removed to hospital and detained. This power appears to be used sparingly.

In spite of the lack of constitutional protection, Britain does appear to be taking an informed and unobtrusive approach to the disease.

\section{Quarantine}

One area of constitutional relevance which has aroused considerable debate with regard to AIDS and HIV is that of quarantine. Although it has definite legal standing (13), the use of quarantine procedures has, unfortunately, been dogged by its potential to harass minority groups (14). Any attempt to quarantine those with AIDS or HIV must guard itself against being used simply as a means to exclude the socially disfavoured.

Secondly, quarantine has traditionally been used to cope with diseases that are either highly contagious or else only contagious for a short period of time (15). AIDS and HIV are neither of these. If a quarantine was established on the basis of being seropositive then it would catch a large number of people who only have the virus and who are otherwise asymptomatic - a condition that could endure for the rest of that person's life. Further, vast economic resources would be required to manage such an undertaking, especially if the quarantine were to continue indefinitely. If it were done solely on the basis of those diagnosed as having AIDS, then it would fail to stop the spread of the disease as only a small proportion of those who are infected and who can transmit the virus can actually be diagnosed as having AIDS.

A quarantine might, however, operate in particular situations or with particular groups of people.

One such group is prisoners. Two American cases have held that it is permissible to quarantine prisoners with AIDS (16), although both emphasise that what happened in prison was unlikely to be upheld in society at large. It appears to be the case in the United Kingdom that prisoners who are known to be seropositive are quarantined (17). Another category are those who continue to act in a manner that will put others at risk. Here, every effort should be made to educate the individuals concerned - it is cheaper and less onerous on individual rights than quarantine (18). 
Under the British Public Health (Control of Diseases) Act 1984, quarantine must only be used in exceptional circumstances and even then it may be difficult to enforce. Fabian Bridges was an indigent male homosexual with AIDS who reportedly continued to have considerable sexual activity in a number of American cities. After several unsuccessful official attempts to restrain him, the local gay community provided him with a place to stay and supervision until his death. An enlightened policy of providing worthwhile care to AIDS sufferers may well prove to be the most successful method of encouraging the vast majority of them to desist from practices that put others at risk.

For those few who do persist, the deprivation of liberty which quarantine entails demands that those who are quarantined should be entitled to significant procedural protections and there is a need to review such administrative actions. How the administrative law will develop in this field is still largely a matter of speculation but everyone should be aware of the inadequacies and severities of the use of quarantine. It should not be used lightly.

\section{Medico-legal matters: a) confidentiality}

There is a genuine worry that if those who are at risk or who actually have contracted AIDS or HIV are not protected by a legal obligation demanding confidentiality, then these people will be slow to come forward and more people may be put at risk. But it has already been noted that there are situations where the interest of the individual can be overtaken by public interest. In the United States, the right of privacy is not explicit in the Constitution, but a right to privacy has been held to exist in certain medical matters (19). Further, state constitutions and laws may provide protection against the invasion of privacy, although statutes have also been passed requiring doctors to inform the relevant authorities that a patient has a communicable disease. When the information is passed on to these authorities, there is a definite need to protect the individual from the risk of the information falling into the hands of third parties, such as insurance companies.

In one American case (20) a psychiatrist was held to have a duty to warn a woman that his patient was contemplating killing her. It is unclear how the American courts will interpret this in dealing with the issue of liability for failure to inform a third party of a patient's antibody-positive status.

A few states have adopted specific legislation safeguarding the confidentiality of individuals who are tested for the presence of the AIDS virus at blood banks and alternative test sites. Some states prohibit the use of a positive test result to determine eligibility for disability, health or life insurance or to terminate employment. Particularly regarding test results, there is a very strong argument for saying this information should only be disclosed once a written consent has been given (21).

In the United Kingdom, General Medical Council guidelines permit the disclosure of confidential information where the 'public interest' demands that the doctor's duty to maintain confidentiality be overridden. The doctor should first endeavour to persuade the patient if he is going to tell another and do his utmost to obtain that patient's consent. But the doctor must also balance, against his patient's interest, the risk to other individuals. When the doctor reasonably foresees that non-disclosure poses a real risk of harm to a third party then he should be free to warn that third party. Thus a doctor could tell the sexual partner or partners of someone with the disease about his patient's condition, provided he had first sought the approval of that patient and this had been refused.

Similarly, the National Health Service (Venereal Diseases) Regulations 1974 (22) make a specific exception to the duty on health authorities to ensure that the identity of a sexually-transmitted disease sufferer is kept secret where another person can be treated or the disease can be prevented from spreading. Only those people, though, who are in a high-risk category need be told and others, such as even the family and friends of a sufferer, far less their employers or insurers, should not be informed.

Research has to be done into both AIDS and HIV. To allow this and, at the same time, to offer sufficiently stringent safeguards for the patient's confidences a strong case can be made for a legislative initiative (23).

\section{Medico-legal matters: b) testing}

At present, there exist a number of techniques which can test for the presence of antibodies to HIV in the blood, but it must be emphasised that there is no test for AIDS itself. This significant limitation should be coupled with the fact that false results are possible from such tests, especially during the latency period between contracting the virus and being found seropositive. From an individual's viewpoint, taking the test is a significant act and being found seropositive can have a devastating effect on one's lifestyle. Because of this there should be counselling both before and after the testing procedure and any patient who volunteers to submit to the test should make an informed decision to do so. Again a balance must be struck which protects those who have the disease and which also protects the healthy from the disease. Those who feel themselves to be at risk should be allowed to determine whether they are seropositive and yet to force them to do so or to do this without their assent may well drive them away from treatment and cause difficulties for a prevention strategy.

It is largely for this reason that universal mandatory testing has been rejected in both Britain and the United States (although there is also the question of cost). Yet it may be worthwhile to permit mandatory testing of special groups, provided there is adequate justification for overriding individual rights. In most instances these justifications will not exist. For example, although it would be unnecessary to test all those who are in hospital, one might test patients in dialysis units 
because of the dangers of transmission. Also, there are factors peculiar to the prison environment which may mean that testing is acceptable.

Many doctors have felt that they are at danger from the virus and they have accordingly advocated testing without the consent of the patient. Obviously this is because they realise that performing such an act can be upsetting to the patient, to say nothing of the devastation a positive test result may bring. Doctors' fears are understandable but they should not lose sight of the interests of their patients. Patients do have a recognised legal right to determine what is done to their own bodies and if this is not respected then the patient may be able to allege battery or 'unlawful touching' by the doctor or possibly negligence for professional misconduct.

Considerable discussion has centred on this topic in Britain, particularly at meetings of the British Medical Association (BMA). Counsel's opinion has stated that patients should be told if they are to be tested for HIV, and that they should agree to the testing (24). If they do not then they should be treated as if they are infected. The current position of the BMA is that any doctor who tests patients without consent must be prepared to defend that decision before the courts or the General Medical Council.

The American Medical Association has voted against the mandatory testing of those groups at high risk of infection with HIV (25)-instead doctors should encourage those at risk to take the test.

A problem has arisen in respecting individual patients in this way in that it makes charting the progress of the disease very awkward. To remedy this what is known as anonymous testing has been introduced, initially in the United States and more recently in the United Kingdom as well (26). By this patients are tested for the virus without giving their consent, but this does not allow either doctors or patients to discover whether a test was positive and while certain information about the patients is retained, their identities remain secret. Although this poses a number of moral problems (27) it would be difficult to allege any legal wrong, particularly if such testing proves successful in charting the spread of the disease and thus facilitates the limitation of that spread.

\section{Criminal law}

Perhaps predictably the emergence of the disease has been accompanied by calls for the stricter enforcement of the criminal law, so that laws against prostitution and commercialised sex and prohibitions on 'sex facilitating emporia' shou!d all be vigorously upheld (28). Such initiatives are unlikely to check the AIDS epidemic as they are unlikely to bring those afflicted into the open. Others have argued that the role of the criminal law in the AIDS crisis should only be a minor one: in areas such as prostitution and drug abuse the criminal law does not really manage to change behaviour and the existence of too strict laws can be damaging to respect for the law and legal institutions.
However, if a person knowingly transfers the virus to another, or knowingly puts another at risk through sexual intercourse, then that person may have committed a crime. While reference must be made to this, it is highly dubious whether such an action can be used as a means of preventing the spread of the disease.

In the United States it has been argued that passing on the virus might be homicide or attempted murder, or criminal assault. Yet, all of these present a number of difficulties if they are to be fitted within the existing legal framework; if it is desired to make such conduct criminal, it may be better to consider legislation.

In the United Kingdom, the criminal law of Scotland diverges from that of England and Wales. For the latter, the highly criticised $R v$ Clarence (29) decision held that a man who passed on gonorrhoea to his wife was not guilty of assault under S20 or S47 of the Offences Against the Person Act 1861. But a prosecution may be brought under S23 of the Act which prohibits maliciously administering any poison or other destructive and noxious thing (30). The 1861 Act does not apply in Scotland, where it has long been recognised that 'all intentional infliction of physical injury is criminal'. This was relied on in a recent decision that held the sale of 'glue sniffing kits' to children to be criminal (31). It may, therefore, be possible to prosecute someone for assault by alleging that he or she had wilfully and recklessly infected another with the virus by sexual intercourse. A major caveat must be stated here; it may well prove impossible to show in court that a particular person transferred the virus to another, given the latency period of the virus and the possibility of other contacts.

As a footnote it is worth noting that the AIDS virus may well prove to have an impact on other areas of criminal law. For example, AIDS and fear of the disease may be used as a 'defence' to a criminal charge (32) or to aggravate a criminal offence (33).

How the criminal law will react to these developments will depend on the circumstances of the different cases.

\section{Tort law}

Instead of relying on the criminal law, a 'wronged' individual might consider turning to tort as a means of redress for having contracted the virus. There are a number of different heads under which a tort action for sexual transmission of the virus could be raised (34) but the most significant are those of negligence or battery.

If one is to succeed in a negligence action then one must prove three things. Firstly, there needs to be a legal duty owed by the defendant to the plaintiff, which must have been breached. However, the exact legal standing of sexual partners - particularly if they are not married - is very uncertain (35). Secondly, there needs to be a causal connection between the act or omission complained about and any resulting damages claimed. Given that there could well be other sexual contacts before symptoms manifest themselves proving this could be almost impossible. And thirdly, there must have been damages or loss resulting from the breach of 
duty. Here questions of contributory negligence and voluntary assumption of risk can be raised, together with any time restrictions that may be imposed on raising an action under the legal doctrine of limitation. One can, therefore, readily appreciate that the chances of success in such actions are likely to be very low indeed.

A battery action could circumvent many of these difficulties, but in order to show the requisite intention for this 'unlawful touching' it would probably be necessary to show that the defendant knew about his or her infectious condition and this could be awkward to prove.

Additionally, as with criminal law, punishment or compensation is scant redress for those who have acquired a potentially lethal condition. Particularly in the civil action there is a danger, given the protracted nature of such legal proceedings and the length of time that the condition takes to manifest itself, that either the victim or the culprit will have died and so little beneficial vindication will be secured.

In America there has also arisen the question of whether liability could be attached to any party where blood products transmit the AIDS virus or other similar diseases (36). But as nearly all jurisdictions have taken the opinion that the supplying of blood is a service and not a product, and hence a successful claim must meet the rigours of proving fault rather than relying on strict product liability, one's chances of success in such an action are very slim.

\section{Debilitating effects of the virus}

As the incidence of the disease increases there will be a concomitant increase in legal attention as to how people with AIDS look after their affairs. Without wanting to appear morbid, this should open up a 'new market' for the lawyer - not only in the control of the patient's financial matters, but also in directing the patient's medical management.

People with AIDS are usually comparatively young and may well not have considered how to distribute their estates on death. Homosexuals may need to make greater efforts to ensure that their estates are passed on to those closest to them after their deaths. To discuss these issues is hardly cheering, but many may feel happier for having organised their affairs responsibly. Additionally, the disease is known to affect brain tissue and while the extent of this is, at present, uncertain, it could mean that AIDS victims can only play a gradually decreasing role in the conduct of their affairs.

Regarding medical matters, there is in California the Durable Power of Attorney for Health Care Act 1984 which allows patients of sound mind to designate others to make their health-care decisions for them if they should become incompetent. In the United Kingdom, several recent cases (37) have pointed to the inadequate provisions for the giving of consent to medical treatment when a person is incapable of giving that consent personally. At present, victims would be well advised to talk matters through with their doctors and inform them in advance, perhaps even in writing, about how they would like to be treated.

\section{Employment law}

Testing a workforce can arouse strong ethical objections (38) but it may be justified in economic terms. In the United States, the issue of employment discrimination against those seen as being at risk of AIDS or HIV has hinged on the issue of whether AIDS can be classified as a 'handicap' or 'disability' under federal law and, in particular, whether it comes within the terms of the Rehabilitation Act of 1973. Shuttleworth $v$ Broward County (2) held that the dismissal of an employee because he had AIDS constituted discrimination against a handicapped person, which was unlawful.

More recently, the Supreme Court held that a teacher who suffered from tuberculosis and was dismissed from her job could be considered as handicapped under the 1973 Act and was protected from discrimination (39). Although the court said that the ruling did not touch the question of whether AIDS would be covered by the Rehabilitation Act, this could provide a legal precedent to do just that. It should be noted that the 1973 Act only covers those employed under federal programmes and so its application is limited.

In the United Kingdom AIDS is not a notifiable disease. Consequently there is no obligation on an employee to report to his employer that he has the virus or the syndrome.

UK Department of Employment guidelines state there is no risk to the public where there is no contact with bodily fluids of an infected person, that few jobs involve such contact and that the majority of employees are therefore safe from infection at work. On the other hand, some employers might feel that because AIDS is not a notifiable disease and because their employees are under no general obligation to disclose their antibody status there is sufficient reason for demanding such a test (41), although employers should inform their employees in advance about such tests.

Should an employee be dismissed, either because he is perceived as being at risk of AIDS or the virus, or because he has been shown to be seropositive, then he may have a claim for unfair dismissal. To counteract this, an employer could either rely on a defence that the employee's sickness and absence from work justified dismissal or that there was 'other substantial reason' for ending employment. There would be difficulty in upholding the latter defence, unless a group of employees were refusing to work with the particular individual. In such a case, it may be better to refer the matter to a recognised industrial reconciliation procedure.

Limits on testing within employment are inappropriate when an applicant presents himself for a new appointment. A limited degree of protection may be available under legislation preventing indirect discrimination on the grounds of sex (42) but there is significantly greater danger of discrimination at this 
stage rather than in continuing employment, and fewer safeguards to tackle it.

\section{Insurance}

The matter of insurance has considerably greater importance in America than it does in Britain, because health insurance schemes are relied upon to meet American hospital fees whereas British hospitals are publicly funded. When one looks at the heavy costs of caring for the AIDS patient, it appears that if these people can be successfully excluded by the insurance companies, Medicaid will be forced to shoulder an overwhelming financial burden (43). Some states prohibit insurance companies from requiring applicants to take the antibody test, but, even where this does happen, the insurance companies are using substitutes for these tests or else denying new policies on social grounds. It may be that steps should be taken to prevent discrimination against sufferers where health insurance is concerned (44) but, given that a level of discrimination is the essence of insurance, it will be difficult to exclude testing from life insurance matters (45). Efforts should be made to prevent insurance companies from having access to confidential records, and those who are concerned by such developments should be informed of other financial protection they can use.

\section{Children at school}

Many parents are very worried by the AIDS virus and will go to great lengths to prevent their children being exposed to it. In America District 27 Community School Board $v$ Board of Education (46) held that children with AIDS should not automatically be excluded from school. Overwhelming medical evidence that AIDS was not transmissible in the classroom setting suggested that a policy of excluding all children with AIDS from school would violate federal law and the children's rights to equal protection. However, some local school districts in America have barred entry of children with AIDS, even in states that have issued guidelines against exclusion.

In Britain, a similar policy has been adopted (47); emphasis has been placed on the fact that the benefits of schooling for the child far outweigh any risk of transmission and those involved in education should be aware of the potential isolation of a child known to be infected. At present this appears to have been successfully implemented in practice (48).

\section{Prisoners}

Prisoners on both sides of the Atlantic are separated from others on the basis of their HIV status. Can this policy of interfering with this aspect of individual liberty be justified in prison? It is known that both intravenous drug use and sex, sometimes forced, do occur in prison. Condoms may be introduced to prisons but they are hardly likely to be used in forced sex and sterile syringes and needles are even less likely to be freely distributed in prisons. The institutional nature of prison already represents a substantial reduction in one's freedoms and it is easier to permit testing and segregation in these circumstances. Nevertheless, it should be official policy not to test those who are detained awaiting trial, but only those who have been found guilty.

\section{Prostitutes and intravenous drug users}

It is often claimed that prostitutes and intravenous drug users are the means through which AIDS will be heterosexually transmitted to the general public. A 1987 study suggests that it is, in fact, intravenous drug use which poses the vastly greater risk (49). The law must prevent further spread of the virus, and it may well be feasible to contain the spread of infection from prostitutes. Prostitution could be de-criminalised and registration introduced but this is an unrealistic suggestion. Instead, prostitutes should be encouraged to accept regular screening for sexually transmitted diseases and attempts should be made to satisfy the prostitutes' desire for more comprehensive health education. Intravenous drug users pose more complicated problems. Drug addicts are among the most difficult people to educate and many of them will have reconciled themselves to the fact that their habit is going to kill them anyway. A worthwhile effort can still be made to help this group and this should take a threepronged approach, with the backing of the law where necessary. Firstly, sterile equipment should be made available; secondly, health education should be targetted on those groups who need it; thirdly, infected users should be identified and then diverted into treatment.

\section{Conclusion}

How will the law continue to treat this disease? Firstly, mention has only been made here of a few areas of the law on which AIDS and HIV have had an impact, there are bound to be many more legal issues that will arise in the future. Secondly, knowledge of the disease and its effects on people is rapidly expanding. The law must reflect this developing understanding and move forward with medical and social sciences. To achieve this it is essential that a high level of inter-disciplinary dialogue is encouraged. Throughout this period of change, the courts must endeavour to protect the interests of public health and of the afflicted or at-risk individual. Too strident a line on public health will prevent those at risk coming forward; too strident an approach favouring the individual may put more people at risk of the disease. As prevention must remain the overall strategy both of these interests must be assessed against the other and a compromise reached.

These equitable considerations are reflected in the leading British case concerning the disease $X v Y(50)$, which held that the public interest in preserving the confidentiality of hospital records identifying people with AIDS outweighed the public interest in the freedom of the press to publish such information. The reasoning behind this was that those with the disease should not be deterred from going to hospital to seek 
treatment because of a fear of discovery and that free, informed debate about the disease could take place without publication of this confidential information. It is to be hoped that future litigation involving the disease will maintain this enlightened approach.

Alistair Orr LL B, Diploma in Legal Practice, Balliol College, Oxford OX1 3BF. Mr Orr is currently working on a doctoral thesis, Giving Consent to Medical Treatment.

\section{References}

(1) Banks T L. The right to medical treatment. In: Dalton $\mathrm{H}$ L, Burris S, eds. AIDS and the Law. New Haven and London: Yale University Press, 1987:176.

(2) Matthews G W, Neslund V S. The initial impact of AIDS on public health law in the United States - 1986. Fournal of the American Medical Association 1987; 257:344-352.

(3) Milne S. Nurses ordered to care for AIDS victims. Guardian 1986 Dec 3.

(4) Smith T. AIDS: a doctor's duty. [editorial] British medical journal 1987; 294:6.

(5) Gillon R. Refusal to treat AIDS and HIV positive patients. British medical journal 1987; 294:1332-1333.

(6) Cotton D J. The impact of AIDS on the medical care system. Fournal of the American Medical Association 1988; 260: 519-523.

(7) Anonymous. The constitutional rights of AIDS carriers. Harvard law review 1986; 99:1274.

(8) Merritt D J. The constitutional balance between health and liberty. In: AIDS, public health and civil liberties. A Hastings Center Report special supplement. 1986 Dec 2.

(9) 466 F Supp 487 (1978).

(10) Frank C. AIDS data-sharing: help sought to combat bias. American Bar Association journal 1986; 72:22.

(11) Roden R. Educating through the law: The Los Angeles discrimination ordinance. UCLA law review 1986; 33:1410.

(12) S I 85/434.

(13) United Kingdom - Public Health (Control of Diseases) Act 1984; United States - Facobsen $v$ Massachusetts 197 US II (1905).

(14) For example Korematsu v US 323 US 214 (1944).

(15) Parmet W E. AIDS and quarantine: the revival of an archaic doctrine Hofstra law review 1985; 14:53.

(16) La Rocca $v$ Dalsheim 120 Misc 2d 697 (1983) and Cordero $v$ Coughlin 607 F Supp 9 (1984).

(17) Hansen O, McFadyean M. AIDS in prison. The Observer 1987 Nov 1:53.

(18) Gleason J A. Quarantine: an unreasonable solution to the AIDS dilemma. Cincinnati law review 1986; 55:217.

(19) Roe $v$ Wade 410 US 113 (1973).

(20) Tarasoff $v$ Regents of the University of California 551 P 2d 340 (1976).

(21) Weldon-Linne M M, Weldon-Linne C M, Murphy J L. AIDS virus antibody testing: issues of informed consent and patient confidentiality. Illinois bar journal 1986; 75:206.
(22) SI 74/29.

(23) Gray J N, Melton G B. The law and ethics of psychosocial research on AIDS. Nebraska law review $1985 ; 64: 637$.

(24) Sherrard M, Gatt I. Human immunodeficiency virus (HIV) antibody testing. British medical journal 1987; 295:911-912.

(25) Anonymous. AIDS monitor. New scientist $1987 \mathrm{Ju}$ 23:23.

(26) Cook S. Go ahead for mass AIDS tests. The Guardian 1988 Nov 24

(27) Gillon R. Testing for HIV without permission. British medical journal 1987; 294:821-823.

(28) Robinson D J. AIDS and the criminal law: traditional approaches and a new statutory proposal. Hofstra law review 1985; 14:91.

(29) (1888) 22 QBD 23.

(30) Farlin G, Wauchope P. AIDS and the criminal law. Law Society's gazette 1987 Mar 25:884.

(31) Khaliq v HMA 1984 SLT 137.

(32) D P P v Fountain [1988] Crim LR 123 and $R v$ Fisher [1987] Crim LR 334.

(33) $R$ v Malcolm [1988] Crim LR 189

(34) Hermann D H J. Torts: private lawsuits about AIDS. In: Dalton $\mathrm{H}$ L, Burris S, eds. AIDS and the law. New Haven and London: Yale University Press, 1987:153.

(35) Hegarty $v$ Shine (1878) 4 LR Ir 288 Cf Kathleen $R v$ Robert B 150 Cal App 3d 992 (1984).

(36) Franklin M A. Tort liability for hepatitis: an analysis and a proposal. Stanford law review 1972; 24:439.

(37) The most recent decision is $\operatorname{Re} F$. The new law journal 1989; 139:183.

(38) Bayer R, Levine C, Wolf S M. HIV antibody screening. Fournal of the American Medical Association 1986; 256:1768-1774.

(39) School Board of Nassau County v Arline 107 S Ct 1123 (1987).

(40) Department of Employment/Health and Safety Executive. AIDS and employment, 1986.

(41) Fagan N, Newell D. AIDS and employment law. New law journal 1987; 137:752.

(42) Southern C, Howard G. AIDS and employment law. London: Financial Training Publications, 1988: 46-49.

(43) Iglehart J K. Health policy report: financing the struggle against AIDS. New England journal of medicine 1987; 317:180.

(44) Shatz B. The AIDS insurance crisis: underwriting or overreaching? Harvard law review 1987; 100:1782.

(45) Clifford K A, Iuculano R P. AIDS and insurance: the rationale for AIDS-related testing. Harvard law review $1987 ; 100: 1806$.

(46) 130 Misc 2d 398, 502 NYS 2d 325 (1986).

(47) Department of Education and Science and Welsh Office. Children at school and problems related to AIDS, 1986.

(48) Steele D. Scots AIDS girl backed on first day at primary. Glasgow Herald 1988 Aug 19:3.

(49) For example Moss A R. AIDS and intravenous drug use: the real heterosexual epidemic. British medical journal 1987; $294: 389$.

(50) [1988] 2 A11 ER 649. 